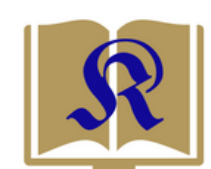

KURIOS
KURIOS

(Jurnal Teologi dan Pendidikan Agama Kristen)

ISSN 2615-739X (print), 2614-3135 (online)

Vol. 4, No. 2, Oktober 2018 (107-117)

http://www.sttpb.ac.id/e-journal/index.php/kurios

\title{
Analisis Kisah Para Rasul 15 Tentang Konflik Paulus dan Barnabas serta Kaitannya dengan Perpecahan Gereja
}

\author{
Sonny Eli Zaluchu \\ Pascasarjana, Sekolah Tinggi Teologi Baptis Semarang, Indonesia \\ gloryofgodmin@gmail.com
}

\begin{abstract}
The separation of Paul and Barnabas in Acts 15 is often used as a ground of foundation for the occurrence of separation or precisely, division, in the church and ministry. This article attempts to review the root causes of the conflict between Paul and Barnabas as a reflection for the church in dealing with and managing conflict. The separation of Paul and Barnabas as a biblical foundation for supporting church division / service for the noble purpose of evangelism is not right and out of biblical paradigm. The ongoing conflict between Paul and Barnabas was not a conflict that gave rise to hostility, rivalry or an attitude of attack as the phenomenon commonly encountered in church or ministry. The separation of Paul and Barnabas is a strategic decision that results in expanding the range of the spread of the gospel of Christ.
\end{abstract}

\begin{abstract}
Abstrak
Perpisahan Paulus dan Barnabas di dalam Kisah Para Rasul 15 sering menjadi alasan bagi terjadinya permisahan, atau tepatnya perpecahan, di dalam gereja dan pelayanan. Artikel ini mengulas akar masalah konflik Paulus dan Barnabas sebagai refleksi bagi gereja dalam menghadapi dan mengelola konflik yang mengarah pada perpecahan. Menggunakan perpisahan Paulus dan Barnabas sebagai patron alkitabiah untuk mendukung perpecahan gereja atau pelayanan dengan alasan demi pekabaran Injil, rasanya kuranglah tepat. Konflik yang berlangsung antara Paulus dan Barnabas bukanlah konflik yang melahirkan sikap permusuhan, persaingan atau sikap saling serang sebagaimana fenomena yang umum ditemui di dalam perpecahan gereja/pelayanan. Perpisahan Paulus dan Barnabas adalah sebuah keputusan strategis yang menghasilkan perluasan jangkauan penyebaran Injil Kristus.
\end{abstract}

Article History

Submit:

24 August 2018

Revised:

20 October 2018

Accept:

25 October 2018

Keywords

The Acts 15;

church's division;

Paul and Barnabas; conflict; separation

Kata kunci:

konflik; Paulus;

Barnabas; Kisah Para Rasul 15; perpisahan, perpecahan gereja 


\section{Pendahuluan}

Paulus dan Barnabas tergolong sebagai misionaris pertama yang dipakai oleh Roh Kudus untuk memberitakan Injil di wilayah Asia Kecil. Hasil pekerjaan mereka yang luar biasa itu menjadi cikal bakal kehadiran jemaat dan gereja. Pada awalnya, Paulus adalah tokoh yang menjadi pioner pasca perjumpaan supernaturalnya dengan Yesus dalam perjalanan ke Damsyik. Disitu, Paulus mengalami konversi dari seorang penganiaya Kristus menjadi pemberita utama firmanNya. Penolakan yang Paulus alami di Yerusalem akibat faktor latar belakangnya sebagai seorang Rabi dan intelektual Yahudi, memaksanya keluar dan pergi ke Asia Kecil dan menjadi ujung tombak pemberitaan Injil di sana. Di dalam perjalanan pemberitaan injil tersebut, Paulus berjumpa dengan Barnabas dan keduanya akhirnya bekerjasama untuk mengajar jemaat dan memberitakan Injil.

\section{Paulus dan Barnabas}

Paulus atau bernama Saulus dan lahir di Tarsus, sebuah kota besar di Kilikia. Pemerintahan Romawi berkuasa atas wilayah ini dan menjadi bagian dari propinsi Siria. Keluarganya adalah Yahudi yang taat. Latar belakang ini mempengaruhi pembentukan prinsip prinsip dan ajaran Yahudi yang keras di dalam dirinya. Menariknya, Saulus adalah seorang warna negara Romawi, sehingga selain bernama Ibrani Saul, ia juga bernama Paulos, sebuah identitas cognomen yang umum dijumpai sebagai nama identitas Romawi seseorang di masa itu. Jadi sesungguhnya, Paulus punya dua nama, sebagai orang Ibrani dan sebagai warga negara Romawi. Dengan demikian, pertanyaan mengenai catatan Kisah Rasul, “Tetapi Saulus, juga disebut Paulus, yang penuh dengan Roh Kudus, menatap dia," (Kisah 13:9), menjadi jelas. Kelak, nama romawi ini yang lebih populer dan dipakai Paulus untuk menjelaskan identitas dirinya yang baru setelah mengalami konversi.

Setelah pertobatannya, Paulus sempat mengalami penolakan karena latar belakangnya sebagai pelaku aniaya orang percaya. Orang ini ikut menyetujui pembunuhan Stefanus, martir pertama dalam kekristenan. Atas inisiatif sendiri, Saulus menjadi salah satu pelaku utama aniaya di Yerusalem terhadap murid-murid dan orang-orang percaya. Kisah Para Rasul mencatat, "Tetapi Saulus berusaha membinasakan jemaat itu dan ia memasuki rumah demi rumah dan menyeret laki-laki dan perempuan ke luar dan menyerahkan mereka untuk dimasukkan ke dalam penjara" (Kisah Rasul 8:3). Tindakannya itu berada di dalam legalitas para tokoh Agama Yahudi di Yerusalem. Saulus memburu hingga ke luar kota. Suatu kali dalam menjalankan rencananya untuk menangkap orang-orang percaya di Damsyik, Saulus meminta surat kuasa dari Imam Besar untuk dibawa kepada majelis-majelis Yahudi di 
Damsyik, "supaya, jika ia menemukan laki-laki atau perempuan yang mengikuti Jalan Tuhan, ia menangkap mereka dan membawa mereka ke Yerusalem" (Kisah Rasul 9:2). Rupanya, perjalanan inilah yang menjadi titik balik di dalam hidupnya. Perjalanan ke Damsyik, menurut Hoerber, adalah titik balik yang mengubahnya dari Saulus sang pemburu menjadi Paulus sang pemberita; dari penganiaya menjadi pelaku utama pembela Injil. ${ }^{1}$ Tetapi Roh Kudus berkuasa atasnya sehingga pertobatan itu membuatnya menjadi bagian penting di dalam kegerakan pemberitaan Injil yang dimulai di Yerusalem. Ia diutus menjadi pembawa pesan Injil bagi bangsa-bangsa Yahudi dan non-Yahudi, bersinergi dengan rasul-rasul di Yerusalem untuk tugas yang sama.

Perkenalannya dengan rasul-rasul dan orang-orang percaya di Yerusalem sempat tertunda. Karena setelah pertobatan, karena dicurigai dan belum sepenuhnya diterima, Paulus pergi ke Arabia dan Damsyik, memberitakan Injil di sana. Catatan di dalam Kitab Galatia menjelaskan hal itu, "juga aku tidak pergi ke Yerusalem mendapatkan mereka yang telah menjadi rasul sebelum aku, tetapi aku berangkat ke tanah Arab dan dari situ kembali lagi ke Damsyik" (Gal. 1:17). Kendati demikian, atas peran Barnabas, pertemuan itu terjadi. Perjalanannya ke Yerusalem menjadi sebuah legalitas bagi misinya yang baru untuk memberitakan Injil. Kisah Rasul mencatat, "Tetapi Barnabas menerima dia dan membawanya kepada rasul-rasul dan menceriterakan kepada mereka, bagaimana Saulus melihat Tuhan di tengah jalan dan bahwa Tuhan berbicara dengan dia dan bagaimana keberaniannya mengajar di Damsyik dalam nama Yesus. Dan Saulus tetap bersama-sama dengan mereka di Yerusalem, dan dengan keberanian mengajar dalam nama Tuhan" (Kisah 9:27-28). Itulah yang menjadi awal pertemuan Paulus dengan Barnabas.

Tidak banyak diketahui asal usul Barnabas di dalam Alkitab. Dia dikenal dengan nama Yusuf dan rasul-rasul memberinya nama Barnabas. Lahir dari keturunan Yahudi dari kaum Lewi dan berasal dari Siprus Hal itu dijelaskan di dalam Kisah Rasul, "Demikian pula dengan Yusuf, yang oleh rasul-rasul disebut Barnabas, artinya anak penghiburan, seorang Lewi dari Siprus" (Kisah 4:36). Dalam perjalanannya ke Antiokhia untuk menguatkan orangorang percaya di sana, berita tentang pertobatan Saulus sampai ke telinganya. Kesempatan itu digunakan Barnabas ke Tarsus untuk menemui Saulus dan membawanya ke Antiokhia. Disana Paulus yang juga disebut Saulus itu mendapat 'covering' rohani. Barnabas tidak kembali ke Yerusalem tetapi atas doa dan penumpangan tangan para pengajar dan nabi di Antiokhia, Roh Kudus memiliki rencana bagi kedua orang ini. Barnabas dan Paulus malah

\footnotetext{
${ }^{1}$ Robert G Hoerber, "Paul's Conversion/Call," Concordia Journal 22, no. 2 (1996): 186-188.
} 
diutus ke Siprus untuk menjadi misonaris. Pada suatu hari ketika mereka beribadah kepada Tuhan dan berpuasa, berkatalah Roh Kudus: "Khususkanlah Barnabas dan Saulus bagi-Ku untuk tugas yang telah Kutentukan bagi mereka." Maka berpuasa dan berdoalah mereka, dan setelah meletakkan tangan ke atas kedua orang itu, mereka membiarkan keduanya pergi.

Oleh karena disuruh Roh Kudus, Barnabas dan Saulus berangkat ke Seleukia, dan dari situ mereka berlayar ke Siprus (Kisah 13:2-4). ${ }^{2}$ Ikut di dalam team kecil itu, seorang muda bernama Markus, sepupu dari Barnabas. Disebut juga Yohanes Markus. Lihat juga catatannya di dalam Kisah 13:5. ${ }^{3}$

Kerjasama pelayanan Paulus dan Barnabas sangat kental dan membawa dampak. Roh Kudus telah memilih dan menetapkan mereka untuk pelayanan tersebut. ${ }^{4}$ Dapat dikatakan bahwa Barnabaslah yang menjadi mentor Paulus di dalam perjalanan pelayanannya yang pertama. Barnabas juga berjasa besar membawa dan memperkenalkan Paulus kepada Rasulrasul di Yerusalem sehingga mendapatkan mandat mereka. Misi pemberitaan Injil mereka berhasil memenangkan dan mengkonsolidasi orang-orang Kristen secara luar biasa di wilayah Siprus, Pamfilia, Lisya dan beberapa kota di propinsi Galatia. Keduanya juga berhasil memenangkan penguasa Siprus dan menyatakan kuasa Allah di sana. Semua kota-kota ini berhasil dijangkau dengan berita Injil. Tidak ada yang kebetulan.

Pertemuan Barnabas dan Paulus di di Tarsus dan kemudian berlanjut di Antiokhia, membawa pengaruh yang besar di dalam memenangkan daerah-daerah yang belum terjangkau Injil. Jumlah orang percaya meningkat drastis. Tetapi pengaruh yang terbesar dialami oleh Paulus, yang menjadi matang di dalam pelayanan pemberitaan Injil dalam bimbingan Barnabas. Mnurut Schnabel, Barnabaslah yang mengenali kemampuan dan potensi di dalam diri Paulus khususnya di dalam penjangkauan orang no-Yahudi sehingga memutuskan untuk menjadikannya rekan pelayanan. Lihat peta perjalanan mereka di gambar di bawah ini.

\footnotetext{
${ }^{2}$ David Mandel, The Ultimate Who's Who in the Bible (Florida: Bridge-Lagos, 2007), 83.

${ }^{3}$ Paul H. Wright, Greatness, Grace and Glory (Jerusalem: CARTA, 2008), 226.

${ }^{4}$ Luther H. Martin, "Gods or Ambassadors of God? Barnabas and Paul in Lystra," New Testament Studies 41, no. 1 (1995): 152-156. doi:10.1017/S0028688500023006
} 


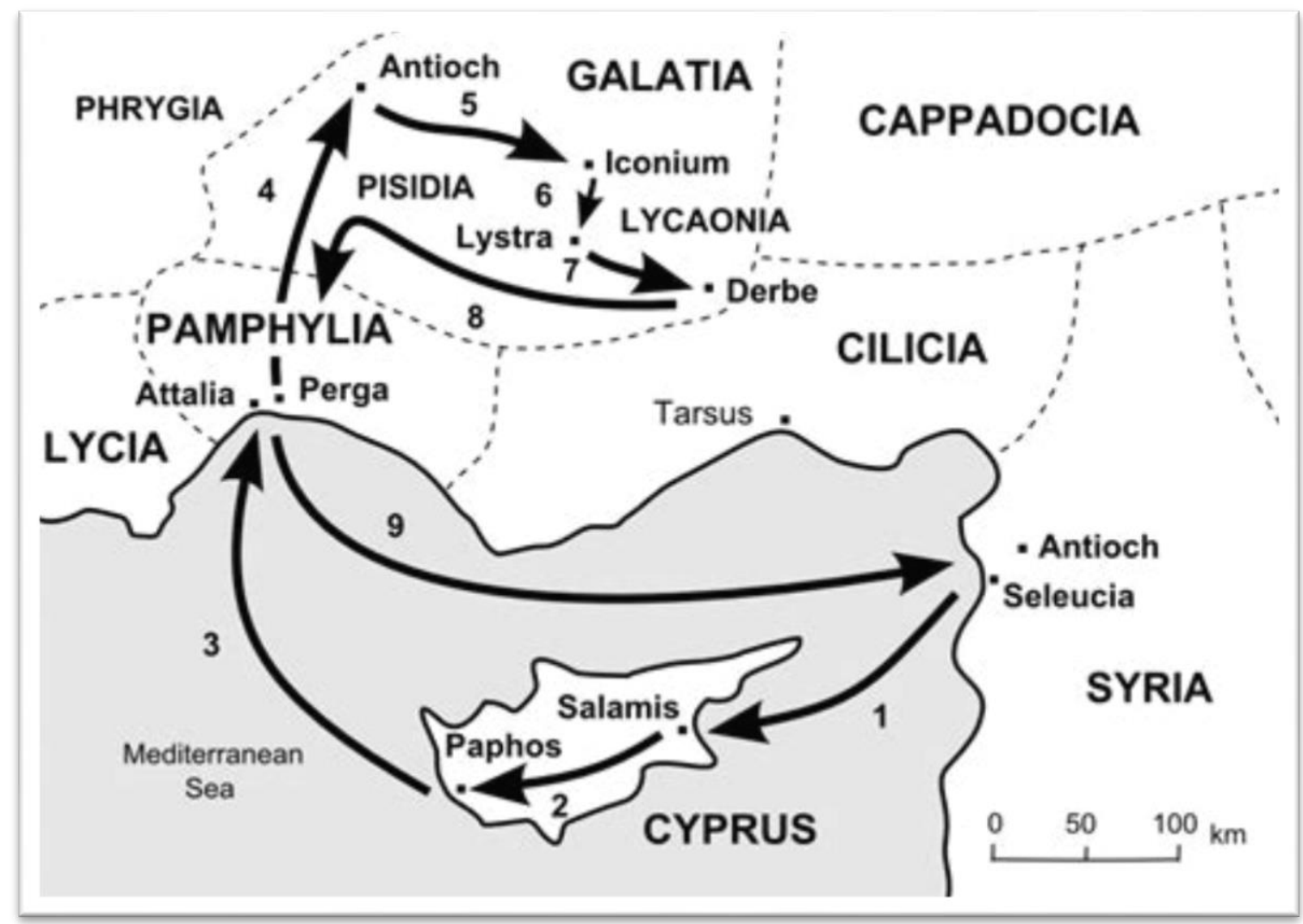

Gambar 1: Peta Perjalanan Paulus dan Barnabas

di dalam Perjalanan Pemberitaan Injil yang Pertama

Penetapan Roh Kudus, pengutusan dan restu para Rasul di Yerusalem dan doa serta penumpangan tangan orang orang percaya di Antiokhia telah menjadi legitimasi spiritual bagi Paulus dan Barnabas untuk bersatu dan bekerjasama melalui potensi masing-masing untuk memberitakan Injil. Dengan kata lain, kerjasama keduanya bukan lahir dari keinginan dan kepentingan pribadi masing-masing tetapi atas peneguhan dan campur tangan Tuhan. Jika Indonesia mengenal duet dwi tunggal Soekarno-Hatta sebagai 'founding father's' Indonesia dan proklamator, maka umat di Asia Kecil melihat Paulus dan Barnabas sebagai dwi tunggal dalam pemberitaan injil di wilayah mereka. Kesatuan hati dan roh kedua orang ini menjadi tonggak lahirnya gereja, dan komunitas Kristen serta transformasi hidup di daerah-daerah yang mereka layani. Lukas mencatat sebagian dari hasil pelayanan mereka, "Mendengar itu bergembiralah semua orang yang tidak mengenal Allah dan mereka memuliakan firman Tuhan; dan semua orang yang ditentukan Allah untuk hidup yang kekal, menjadi percaya. Lalu firman Tuhan disiarkan di seluruh daerah itu” (Kisah 13:48-49).

\section{Metodologi}

Metode dalam artikel ini adalah deskriptif analitik, di mana penulis memberikan deskripsi tentang Paulus dan Barnabas serta persoalan yang terjadi dalam pelayanan mereka. 
Penulis mendeskripsikan teks dalam Kisah Para Rasul 15 untuk memberikan gambaran jelas tentang kedua sosok tersebut. Kemudian persoalan serta latar belakang yang menyebabkan terjadinya persoalan tersebut dianalisis sesuai dengan teks-teks yang ada dalam Kisah Para Rasul 15 tersebut. Analisis teks untuk memberikan landasan kuat tentang terjadinya perpisahan antara Paulus dan Barnabas sebagai sesuatu yang memang harus terjadi dalam rangka menjalankan strategi pemberitaan firman Tuhan.

Selain itu penulis juga menggunakan teks-teks paralel, baik dalam Kisah Para Rasul dan surat-surat Paulus, untuk mendapatkan informasi deskriptif tentang Paulus dan Barnabas serta kaitannya dengan pelayanan mereka. Kisah Para Rasul harus dipahami dalam konteks berpikir Lukas, sehingga konsep-konsep yang dimunculkan baik dalam bentuk narasi dan peristiwa mewakili teologi Lukas. Kisah Para Rasul yang memuat kisah pelayanan rasul-rasul dan gereja mula-mula setelah pencurahan Roh Kudus di hari Pentakosta menunjukkan bahwa kegiatan misi merupakan salah satu karakter yang dihasilkan dari peristiwa itu. ${ }^{5}$ Kegiatan misi yang dilakukan oleh Paulus pun menjadi salah satu tema yang mendominasi dalam Kisah Para Rasul, termasuk perjalanan misinya bersama Barnabas.

\section{Pembahasan}

\section{Munculnya Konflik}

Tim kecil yang terjun di dalam pelayanan misionaris Paulus yang pertama dengan Barnabas dikenal sangat solid. Akan tetapi, situasi itu tidak bertahan lama. Bermula dari perjalanan menuju Pamfilia, Lukas tidak memberi penjelasan mengenai alasannya, tetapi mencatat bahwa Yohanes Markus meninggalkan kelompok kecil itu dan kembali ke Yerusalem. Dalam Kisah Rasul dijelaskan, "Lalu Paulus dan kawan-kawannya meninggalkan Pafos dan berlayar ke Perga di Pamfilia; tetapi Yohanes meninggalkan mereka lalu kembali ke Yerusalem" (Kisah 13:13). Kata Yunani yang dipergunakan Lukas di ayat itu

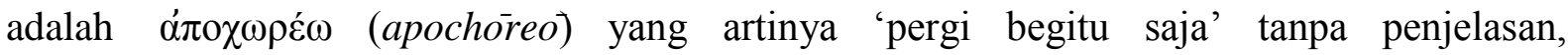
meninggalkan tanggung jawab dan panggilan, dan mengabaikan tugas-tugas yang seharusnya dibebankan kepadanya.

Perginya Markus dari kelompok penginjilan Paulus dan Barnabas kemungkinan besar disebabkan oleh sifat Markus yang sangat Yahudi. Dalam Kolose 4:10 dicatat bahwa Markus merupakan sepupu dari Barnabas sendiri. Anak muda ini tumbuh dan besar di dalam teologi para Rasul di Yerusalem yang kemungkinan besar meyakini bahwa inti pemberitaan Injil

\footnotetext{
${ }^{5}$ Harls Evan R. Siahaan, "Karakteristik Pentakostalisme Menurut Kisah Para Rasul,” DUNAMIS: Jurnal Teologi dan Pendidikan Kristiani 2, no. 1 (2017): 12-28, www.sttintheos.ac.id/e-journal/index.php/dunamis.
} 
hanya kepada orang-orang bernunat dan kaum Yahudi sendiri. Catatan Alkitab menginformasikan bahwa ibu Markus yang bernama Maria, tinggal dan memiliki rumah di Yerusalem. Rumah itu adalah tempat para murid berdoa sewaktu Petrus melarikan diri dari penjara (Kisah 12:12). Markus menjadi saksi hidup dari misi pemberitaan Injil oleh para rasul di tahun-tahun pertama seteleh kematian Yesus di Yerusalem. Pada masa itu penolakan terhadap orang-orang non-Yahudi (khususnya golongan tak bersunat) masih sangat keras. Sampai-sampai Petrus mendapat penglihatan di atas sebuah loteng rumah untuk mengubah pandangannya tentang Kristus bagi semua bangsa. Alasan ini diungkap juga di dalam catatan NKJV yang mengatakan bahwa Markus agaknya tidak menyukai misi pemberitaan Injil kepada orang-orang asing (gentiles). ${ }^{6}$

Setelah selesai dengan tugas misionaris dan kembali mengajar di Antiokhia, Paulus mengajak Barnabas untuk melakukan perjalanan kembali ke daerah dan wilayah dimana mereka pernah memberitakan Injil. Barnabas menyetujui usulan itu untuk kepentingan penguatan jemaat di gereja gereja. Barnabas ingin memasukkan Johanes Markus, kembali ke dalam tim tetapi Paulus keberatan. Lukas mencatat, "Barnabas ingin membawa juga Yohanes yang disebut Markus; tetapi Paulus dengan tegas berkata, bahwa tidak baik membawa serta orang yang telah meninggalkan mereka di Pamfilia dan tidak mau turut bekerja bersama-sama dengan mereka" (Kisah 15:37-38).

Paulus menolak kehadiran Markus ke dalam tim sementara Barnabas bersikeras mengajaknya. Ada kemungkinan bahwa Paulus kuatir Markus mengulang perbuatan yang sama dan meninggalkan mereka untuk kedua kalinya, terlebih setelah menyadari bahwa tantangan di daerah penginjilan Paulus bukan sesuatu yang ringan. ${ }^{7}$ Bahkan dapat juga dipahami bahwa penolakan Paulus tersebut, meminjam istilah yang digunakan oleh Tumanan, sebagai bagian dari tindakan disiplin ${ }^{8}$, terhadap perilaku indisipliner Markus di dalam pelayanan. Mereka dituntut menghadapi peperangan rohani, guru dan nabi palsu serta ajaran-ajaran yang menyimpang. Termasuk didalamnya penguasa-penguasa setempat yang tertutup dan mencurigai pelayanan Paulus. Kedua orang ini akhirnya terlibat di dalam perbedaan pendapat dan perselisihan yang cukup keras, dan tajam. Pasti terjadi adu argumentasi dan masing-masing bertahan dengan pendapatnya. Terlihat dari cara Lukas menceritakan ending-nya, "Hal itu menimbulkan perselisihan yang tajam, sehingga mereka

\footnotetext{
${ }^{6}$ Earl D. Radmacher, ed., NKJV Study Bible, 14th ed. (Nashville: Thomas Nelson, Inc., 1997), 1849.

${ }^{7}$ Frank R.C. De Wit, Lindred L. Greer, and Karen A. Jehn, "The Paradox of Intragroup Conflict: A Meta-Analysis,” Journal of Applied Psychology 97, no. 2 (2012): 360-390. DOI: 10.1037/a0024844

${ }^{8}$ Yohanis Luni Tumanan, "Disiplin Gereja Berdasarkan Injil Matius 18:15-17 Dan Implementasinya Dalam Gereja Masa Kini,” Jurnal Jaffray 15, no. 1 (2017): 31-62. http://dx.doi.org/10.25278/jj71.v15i1.231
} 
berpisah dan Barnabas membawa Markus juga sertanya berlayar ke Siprus. Tetapi Paulus memilih Silas, dan sesudah diserahkan oleh saudara-saudara itu kepada kasih karunia Tuhan (Kis. 15:39-40). Tidak adanya solusi mengenai pokok permasalahan ini, menggiring keduanya untuk mengakhiri krisis dengan berpisah dan menempuh jalan pelayanan masingmasing. ${ }^{9}$

Deskripsi Lukas tentang perselisihan itu terlihat dari pilihan kata yang dipilih untuk menggambarkan situasi yang terjadi yakni 'sharp' istilah yang khusus dipakai untuk menggambarkan pisau yang sangat tajam sehingga dapat membuat semua yang mengenainya luka atau terpotong dengan cepat. ${ }^{10}$ Dalam terjemahan versi KJV tertulis: And the contention was so sharp between them, that they departed asunder one from the other: and so Barnabas took Mark, and sailed unto Cyprus; Hasil dari perbedaan yang tajam itu dituliskan oleh KJ Bible sebagai departed asunder one from the other. Paulus dan Barnabas berpisah dan memilih jalan masing-masing.

\section{Perpisahan: Alkitabiah?}

Perselisihan antara Paulus dan Barnabas diidentifikasi sebagai konflik yang sangat serius di abad-abad pertama perkembangan kekristenan. ${ }^{11}$ Kejadian tersebut cukup untuk menggambarkan bahwa konflik merupakan bagian tak terpisahkan di dalam pelayanan manapun dan yang melibatkan siapapun, khususnya menyangkut terjadinya perbedaan pendapat yang tidak terselesaikan. Jalan pemisahan yang ditempuh Paulus dan Barnabas adalah sebuah model penyelesaian konflik yang tidak mudah untuk diterapkan. Apalagi kedua tokoh ini merupakan panutan di dalam pergerakan pemberitaan Injil kepada bangsa-bangsa lain di luar Yerusalem dimana pelayanan mereka berdua menjadi inspirasi dan teladan bagi orang Kristen mula-mula. ${ }^{12}$ Persoalannya adalah, apa yang mereka lakukan berabad-abad silam, justru menjadi inspirasi bagi orang Kristen masa kini, menempuh jalan pemisahan sebagai solusi terakhir di dalam konflik.

Salah satu hal penting di dalam manajemen konflik adalah menemukan solusi yang menguntungkan di antara pihak-pihak yang bertikai. Akan tetapi kedua tokoh ini gagal menemukan solusi yang mendukung kerjasama lanjutan di dalam pemberitaan Injil di Asia

\footnotetext{
${ }^{9}$ Eckhard J. Schnabel, Paul The Missionary (Illionis: InterVarsity, 2008), 82.

${ }^{10}$ James Strong, Strong's Exhaustive Concordance of the Bible (Iowa Falls: World Bible Publishers, 1986), 48.

${ }^{11}$ A J M Wedderburn, "Paul and Barnabas: The Anatomy and Chronology of a Parting of the Ways," in Fair Play: Diversity and Conflicts in Early Christianity, 2002. In H. Raisanen, I. Dunderberg, C. C. M. Tuckett, \& K. Syreeni (Eds.), Fair play: Diversity and conflicts in early Christianity (pp. 291-310). Brill. Retrieved from https://books.google.com/books?id=cSVNH95ckNUC\&pg=PA291.

${ }^{12}$ Richard Posthuma and Richard A. Posthuma, "Conflict Management and Emotions," International Journal of Conflict Management, 2012: 4-5. DOI: 10.1108/10444061211210797.
} 
Kecil dan sekitarnya. Keduanya bersikeras pada pandangan masing-masing dengan alasan yang sama-sama masuk akal. Sekilas, solusi perpisahan, terlihat baik karena mampu memperluas jangkauan penyebaran Injil. Hal ini juga yang sering dipakai sebagai alasan perpisahan dan menempuh jalan masing-masing, ketika di dalam sebuah organisasi pelayanan atau gereja, gagal menemukan kata sepakat. Marthin Luther mungkin tidak pernah berpikir bahwa 95 dalilnya telah menjadi titik awal reformasi gereja dimana akhirnya terjadi pemisahan, seperti Paulus dan Barnabas pernah lakukan, antara gereja Katolik dan Protestan. Kesan inilah yang ditangkap oleh Aritonang saat membahas dampak reformasi terhadap perpecahan dan maknanya bagi penyatuan gereja. ${ }^{13}$

Jauh sebelumnya, di masa Perjanjian Lama, terdapat narasi perpisahan yang ditampilkan oleh Abraham dan Lot. Keduanya tidak dapat bersama-sama lagi di dalam rombongan yang besar dan harus menempuh jalan masing-masing. Hamba dan pekerja dari masing-masing tokoh ini sering bertengkar memperebutkan wilayah penggembalaan dan sumber air untuk ternak. Tidak ada solusi untuk mereka berdua hidup berdampingan secara damai. Abraham mengambil inisiatif dan berkata kepada Lot. "Janganlah kiranya ada perkelahian antara aku dan engkau, dan antara para gembalaku dan para gembalamu, sebab kita ini kerabat. Bukankah seluruh negeri ini terbuka untuk engkau? Baiklah pisahkan dirimu dari padaku; jika engkau ke kiri, maka aku ke kanan, jika engkau ke kanan, maka aku ke kiri." (Kejadian 13:8-9). Kedua orang ini akhirnya berpisah.

Terlihat bahwa perpisahan yang menjadi ujung sebuah konflik menjadi solusi terakhir ketika tidak ada lagi kata sepakat untuk mengambil keputusan. Hasil negosiasi yang berujung pada ketidaksepakatan akan memunculkan strategic decisions. Scott menjelaskan bahwa sebuah strategic decisions dilakukan dan lahir karena pihak-pihak yang bernegosiasi membutuhkan iklim baru atau situasi yang sama sekali berbeda. Situasi yang lama tidak dapat dipertahankan lagi. ${ }^{14}$ Dengan demikian dapat disimpulkan bahwa konflik yang terjadi antara Paulus dan Barnabas bukan karena permusuhan dan sikap saling serang. Keduanya gagal membangun kesepakatan tentang Markus di satu pihak tetapi dipihak ain, keduanya mengerti bahwa ada tanggung jawab besar di pundak mereka masing-masing untuk meneruskan usaha pemberitaan Injil. Dilihat dari pendekatan komunikasi, keduanya dapat dikatakan gagal menjalin komunikasi yang baik. Meminjam terminologi Lukas yang menggunakan kata

\footnotetext{
${ }^{13}$ Jan S. Aritonang, "Dampak Reformasi Terhadap Perpecahan Gereja Dan Maknanya Bagi Upaya Penyatuan Gereja | Impact of the Reformation on Church Division and Its Meaning for the Effort To Unite the Churches," Jurnal Ledalero 16, no. 2 (2017): 204.

${ }^{14}$ Bill Scott, The Skills of Negotiating, 3rd ed. (Mumbai: Gower Publishing Company, Ltd., 2004), $181-185$.
} 
'tajam' atas perselisihan yang terjadi. ${ }^{15}$ Akan tetapi, karena tuntutan pemberitaan Injil sudah semakin mendesak, tidak ada jalan lain kecuali menempuh jalan masing-masing.

\section{Refleksi Terhadap Gereja dan Pelayanan}

Perpisahan dengan alasan memperluas jangkauan pelayanan seringkali menjadi alasan terjadinya perpecahan di dalam gereja dan ministry. Mencontoh perpisahan Paulus dan Barnabas sebagai pijakan Alkitabiah untuk mendukung perpecahan gereja/pelayanan demi tujuan mulia yakni pekabaran Injil, tidaklah tepat. Konflik yang berlangsung antara Paulus dan Barnabas bukanlah konflik yang melahirkan sikap permusuhan, persaingan atau sikap saling serang sebagaimana fenomena yang umum ditemui di dalam perpecahan gereja/pelayanan. Perpisahan Paulus dan Barnabas adalah sebuah strategic decisions yang menghasilkan perluasan jangkauan penyebaran Injil Kristus. Tidak terdapat jemaat yang pro Paulus atau Barnabas sebagaimana yang lazim mewarnai perpecahan gereja. Sengketa perebutan aset yang berujung pada kekerasan dan tindakan hukum juga tidak terjadi di dalam perselisihan tersebut. Barnabas melanjutkan misi bersama Markus sedangkan Paulus memilih Silas sebagai rekan sekerjanya.

Kesalahpahaman teologis seringkali muncul di dalam melakukan analisis perselisihan Paulus dan Barnabas. Hal ini terjadi karena analisis difokuskan pada perpisahan tanpa mempertimbangkan aspek kontekskual yang melahirkan perpisahan itu sendiri. Bahkan jika ditarik jauh ke depan, perpisahan tersebut tidak pernah sama dengan perpecahan sebagaimana diistilahkan di dalam konflik gereja dan ministry. Dalam suratnya yang kedua kepada anak rohaninya Timotius, semangat rekonsiliasi dengan Markus terbaca sangat jelas. Paulus menulis, " Hanya Lukas yang tinggal dengan aku. Jemputlah Markus dan bawalah ia ke mari, karena pelayanannya penting bagiku" (2 Timotius 4:11). Di situ Paulus menggunakan kata

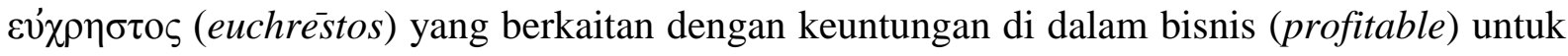
menjelaskan betapa Paulus menganggap Markus sebagai sosok penting di dalam pelayanannya. Kenyataannya, kita tidak pernah melihat dan mendengar, gereja atau minsitry yang mengalami perpecahan dengan menggunakan dalil perpisahan Paulus dan Barnabas, pada akhirnya mengalami rekonsiliasi dan bergabung kembali.

Hal lain yang tidak disadari adalah, apabila dicermati mengenai kelanjutan misi dan panggilan kedua tokoh besar tersebut, pasca perpisahan mereka, catatan tentang Barnabas seolah-olah 'selesai' di dalam kitab Perjanjian Baru. Namanya dan kiprah perjalanan misinya

\footnotetext{
${ }^{15}$ Fred C Lunenburg, "Communication : The Process , Barriers , And Improving Effectiveness," Schooling 1 (2010): 1-11.
} 
seolah berhenti sampai disitu. Bagaimana dengan Paulus? Rasul ini memilih kembali kepada gereja dan umat Tuhan. Hasilnya, rekam jejak pelayanannya tercatat detil di dalam Perjanjian Baru bahkan mewarnai dua pertiga kitab Perjanjian Baru yang menjadi pegangan kehidupan rohani orang Kristen di seluruh dunia hingga saat ini.

\section{Kesimpulan}

Dengan demikian dapat disimpulkan bahwa, alasan perpecahan gereja atau minstry yang menjadikan peristiwa perpisahan Paulus dan Barnabas sebagai landasan Alkitabiah, tidaklah tepat dilihat dari konteks, akar masalah dan kelanjutan pelayanan. Setiap pemimpin yang terlibat di dalam konflik harus memiliki sikap rendah hati sedemikian rupa sehingga di dalam usaha menyelesaikan konflik di dalam pelayanan, selalu menggunakan semangat kesatuan tubuh Kristus dan menghindari perpecahan sebagai pilihan terakhir.

\section{Referensi}

Aritonang, Jan S. "Dampak Reformasi Terhadap Perpecahan Gereja Dan Maknanya Bagi Upaya Penyatuan Gereja Impact of the Reformation on Church Division and Its

Meaning for the Effort To Unite the Churches." Jurnal Ledalero 16, no. 2 (2017): 204.

Hoerber, Robert G. "Paul's Conversion/Call." Concordia Journal 22, no. 2 (1996): 186-188.

Lunenburg, Fred C. "Communication : The Process , Barriers , And Improving Effectiveness." Schooling 1 (2010): 1-11.

Mandel, David. The Ultimate Who's Who in the Bible. Florida: Bridge-Lagos, 2007.

Martin, Luther H. "Gods or Ambassadors of God? Barnabas and Paul in Lystra." New Testament Studies 41, no. 1 (1995): 152-156.

Posthuma, Richard, and Richard A. Posthuma. "Conflict Management and Emotions." International Journal of Conflict Management, 2012.

Radmacher, Earl D., ed. NKJV Study Bible. 14th ed. Nashville: Thomas Nelson, Inc., 1997.

Schnabel, Eckhard J. Paul The Missionary. Illionis: InterVarsity, 2008.

Scott, Bill. The Skills of Negotiating. 3rd ed. Mumbai: Gower Publishing Company, Ltd., 2004.

Siahaan, Harls Evan R. "Karakteristik Pentakostalisme Menurut Kisah Para Rasul." DUNAMIS: Jurnal Teologi dan Pendidikan Kristiani 2, no. 1 (2017): 12-28. www.sttintheos.ac.id/e-journal/index.php/dunamis.

Strong, James. Strong's Exhaustive Concordance of the Bible. Iowa Falls: World Bible Publishers, 1986.

Tumanan, Yohanis Luni. “Disiplin Gereja Berdasarkan Injil Matius 18:15-17 Dan Implementasinya Dalam Gereja Masa Kini.” Jurnal Jaffray 15, no. 1 (2017): 31-62.

Wedderburn, A J M. "Paul and Barnabas: The Anatomy and Chronology of a Parting of the Ways." In Fair Play: Diversity and Conflicts in Early Christianity, 2002.

De Wit, Frank R.C., Lindred L. Greer, and Karen A. Jehn. "The Paradox of Intragroup Conflict: A Meta-Analysis.” Journal of Applied Psychology 97, no. 2 (2012): 360390.

Wright, Paul H. Greatness, Grace and Glory. Jerusalem: CARTA, 2008. 